\title{
FEATURES OF CREATING A HEALTH-PROMOTING TEACHING / LEARNING ENVIRONMENT FOR CHILDREN: THE CONTEXT OF THE DEVELOPMENT OF INFORMATION TECHNOLOGIES IN PRIMARY EDUCATION
}

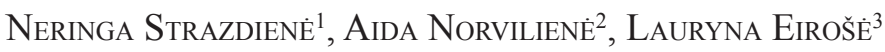 \\ Klaipėda University (Lithuania)
}

\begin{abstract}
The development of information technology (IT) in the process of modern primary education poses new challenges for participants in this process. Despite the fact that the development of IT enhances teaching/learning, and makes it modern and attractive, the unrestricted and irresponsible use of IT can have negative consequences for both the physical and the mental health of younger school-age children. The article analyses problems related to features of creating a healthy child-friendly teaching/learning environment in the context of the development of IT in primary education. A total of 237 primary school teachers in western Lithuania were interviewed by means of a written (questionnaire) survey research method. The research results show that a computer is the main IT tool in the primary education environment. Almost all the interviewed teachers had them in their classrooms. Teachers lack in particular interactive boards and tablets. Only a very small number of teachers had them in their classrooms. The teachers interviewed lack more diverse means of IT in their classrooms, which limits the possibilities for using IT in the education process. The results of the research reveal that although primary school students know about safe use and health-care when working with IT, they are not able to apply the available knowledge in practice. Children lack the acquisition of practical actions and skills in applying them in life situations. Only a third, and even fewer teachers, agreed that while using IT children are able to sit correctly at a desk, protect their eyesight, do eye exercises, coordinate eye and hand movements, etc. Therefore, not only are modern means of IT and their safe installation important for the creation of a healthy child-friendly primary teaching/learning environment in the context of IT, but so is the development of safe and healthy child-friendly behaviour with IT: the regulation and distribution of work time with IT at school and at home, the responsible use of IT; not only the provision of knowledge about the use of IT to students, but also the formation of practical skills and their application in life situations.
\end{abstract}

KEYWORDS: healthy teaching/learning environment, teachers, primary school students, information technology.

JEL CODES: I12, I21; I31.

DOI: http://dx.doi.org/10.15181/rfds.v32i3.2149

\section{Introduction}

The rapid development of new technologies and innovations has an increasing influence on the life of the modern person; it changes the teaching/learning environment, its content and methods. IT increases the efficiency of the process of primary education, enriches the teaching/learning environment, and helps to access

\footnotetext{
Neringa Strazdiene $\mathrm{PhD}$ is a professor in the Faculty of Social Sciences and Humanities at Klaipeda University Research interests: creation of teaching and learning environments, children's health education

2 Aida Norvilienė $\mathrm{PhD}$ is a lecturer in the Faculty of Social Sciences and Humanities at Klaipeda University Research interests: development of teacher competences, pre-school and primary education, education management, study quality E-mail: aida.norviliene@gmail.com Tel.+370 65615640

3 Lauryna Eirošè is a primary school teacher at the Gedminai progymnasium in Klaipeda Research interests: creation of a healthy education/learning environment, primary education E-mail: 1.eirose@gedminai.lt Tel. +37069324417
} 
modern resources and integrate various topics, to develop critical thinking skills, to apply methods of active teaching/learning, and to highlight the individual abilities of a child, etc. (Brazdeikis, 2009; Martišienè, Muleravičienè, 2010; Sangra, González-Sanmamed, 2010; Glahn, Specht, Mwishart, 2011; Wajszczyk, 2014; Holt, 2015; Burianova, Turčáni, 2016; Parigi, 2016; Mirascieva, Petrova, Stavreva, 2017; Lafuente, 2017; Lawrence, Tar, 2018; Vartiainen, Leinonen, Nissinen, 2019).

Nowadays, children are provided the latest IT tools from a very early age. Junior school age is an important period for the maturity, growth and development of a child's personality. During this period, the child grows intensely, and the nervous, heart, cardio-vascular, respiratory and other systems of the organism develop. The human musculo-skeletal system has not yet formed; the bones contain a lot of cartilage, and grow intensely and undergo ossification. The mental development of a child is especially intense at this age; the will-power and the ability to regulate feelings are formed. The irresponsible, unsafe and unrestricted use of IT can have negative consequences for the physical and mental health of a child (Dugdill, Crone, Murphy, 2009; Hastings et al., 2009; Patel et al., 2010; Bacys, 2012; Brunes, Augestad, Gudmundsdottir, 2013; Bassiouni, Hackley, 2014; McCrindle, 2014; Adaškevičienè, Strazdienè, 2017; Chan, Lake, Hansen, 2017; Mertala, 2019).

Natural interest in IT, cognitive needs, curiosity, and the use of IT in the educational process by junior schoolchildren necessitate an inevitable need to manage the process. In order to ensure a teaching/learning environment that is conducive to the development and health of a child, as well as to develop a culture of IT use, it is necessary to assess the risk factors. D. Gudonienè, D. Rutkauskiene and A. Lauraitis (2013) indicate that the quality of learning depends not only on the IT available, but also on its successful use. Nowadays, it is necessary to take into account not only appropriate kinds of IT to use in primary education, but also how to use them safely and effectively, without causing damage to the physical, mental and social development and the health of the child. Accordingly, the problem of identifying and reducing risks to children's health in order to create a health-promoting teaching/learning environment is becoming more evident.

Research object: features of creating a health-promoting teaching/learning environment for the child in the reality of education in terms of IT use.

Research aim: to examine tendencies in IT development in primary education, and to reveal features of creating a health-promoting teaching/learning environment for a child.

Research methods: analysis of scientific literature and documents, questionnaire survey, statistical data analysis.

\section{Research methodology}

The research was carried out during November 2016 and February 2017, by using questionnaire surveys. A research sample was obtained by applying a non-probability convenience sampling technique. A total of 250 questionnaires were distributed, and 237 were returned. The return of questionnaires: $94.8 \%$. The research involved 237 primary school teachers from 23 schools in the west of Lithuania.

The questionnaire for teachers consisted of 16 closed questions. The questions were divided according to topics: demographic data, assessment of the material (physical) learning/teaching environment, the use of IT during teaching/learning activities and leisure time, the positive/negative impact of IT, children's knowledge about the use of IT and physical activity, the time spent by children in front of a screen, the promotion of physical activity in schools, and ways of ensuring children's health while using IT. The article analyses only some of the questions in the questionnaires. Statements in questionnaires were rated according to the five-point Likert scale, with multiple-choice answers ranging from very important (five points) to not at all important (one point). In order to analyse the quantitative data, SPSS Software (version 23.0) and Microsoft Office Excel (2003) were used. In order to analyse the data received, a descriptive statistics method, Chisquared $\left(\chi^{2}\right)$ test, Student's t-test, and Spearman's rank correlation coefficient $\left(\mathrm{r}_{\mathrm{s}}\right)$, were applied.

The participants in the research were briefed and interviewed according to general requirements for the research: before the survey, each respondent was informed about who was carrying out the survey; respondents were provided with information about the research; the anonymity of participants' answers and the 
confidentiality of information received were ensured by emphasising that the survey data would only be used for the purposes of the research (Rupšienè, 2007). Each participant was given an opportunity to complete the questionnaire without being forced, and in an anonymous way. Questionnaires were completed optionally: in educational institutions at a convenient time, or at home.

\section{Results of empirical research}

Analysis of information technologies used in the process of primary education. IT tools facilitate the education process (they enable more effective, individualised, active and conscious learning), and increase students' interest in learning (Vilkoniené, 2009). According to research data, the supply of various technological tools is not abundant in some primary schools, although this should not be so (Are the New Millennium Learners Making the Grade?, 2010). The research aimed to find out what IT tools are available to primary school teachers in the educational environment (Figure 1).

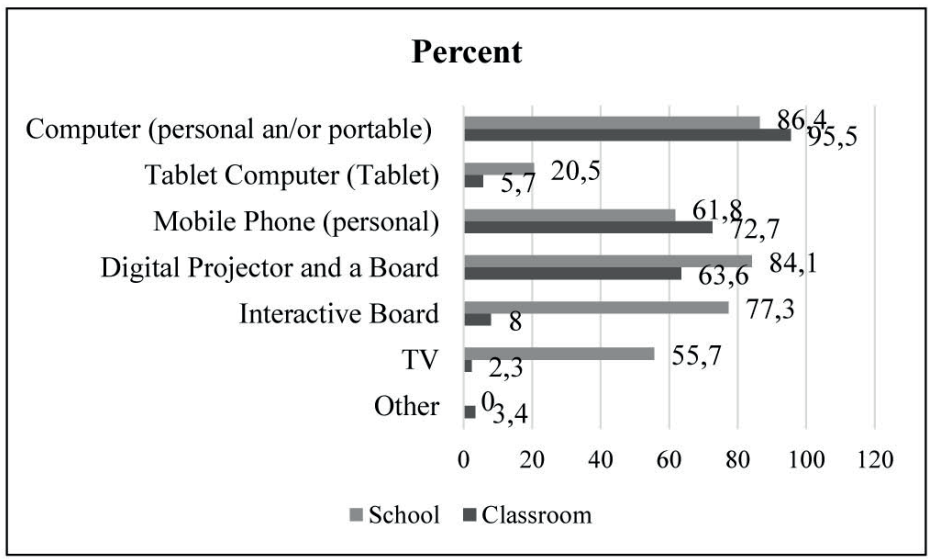

Figure 1. Available IT tools in the primary education environment (in a classroom and school) (\%)

The results of the research reveal that the computer is the dominant IT tool in the primary education environment. Almost all teachers (95.5\%) had a computer in their classroom. A large proportion of students (72.7\%) had personal mobile phones. A total of $63.6 \%$ of teachers claimed to have a digital projector in their classroom. A large proportion of schools $(84.1 \%)$ had a digital projector for shared use. Only $8 \%$ of primary school teachers had an interactive board in their classroom, although $77.3 \%$ of respondents said that their school had one for shared use. Only a small proportion of primary school teachers $(2.3 \%)$ had a television in their classroom. Teachers working in non-urban schools reported statistically significantly more often that there was a television in the school than those working in urban schools $(\mathrm{U}=442.500, \mathrm{p}=0.003$; average response rates of teachers working in urban schools $\bar{X}-32.83$, of teachers working in non-urban schools $\left.-\bar{X}_{-} 45.75\right)$. Only $5.7 \%$ of respondents had tablets in their classrooms, even though about a fifth of respondents (20.5\%) had them in their schools for shared use.

Thus, even though almost all teachers had computers in their classrooms, they were used mostly for teachers' needs in the educational process or in conjunction with a digital projector. There is a particular lack of personal IT tools for students, such as tablet computers, as well as the latest digital tools that help improve the process of teaching/learning.

Technological innovations create preconditions for the successful implementation of innovative educational paradigms, the activation of the educational process, and changes in students' achievements, progress and maturity. According to researchers, if there are no innovative changes in a school, the benefits of IT are minimal (Are the New Millennium Learners Making the Grade?, 2010). The research sought to find out what kinds of IT tools are used by teachers in the teaching process (Table 1). 
Table 1. IT tools used by teachers in the process of teaching/learning (\%)

\begin{tabular}{|c|c|c|c|c|c|}
\hline \multirow{2}{*}{ Statements } & \multicolumn{5}{|c|}{ In the process of teaching/learning } \\
\hline & Never & Sometimes & Often & Every day & $\bar{X}$ \\
\hline Computer (personal and/or portable) & 5.2 & 24.3 & 36.4 & 34.1 & 3.04 \\
\hline Tablet Computer (Tablet) & 69.3 & 13.8 & 12.1 & 4.8 & 1.43 \\
\hline Mobile Phone (personal) & 42.0 & 17.1 & 14.8 & 26.1 & 2.27 \\
\hline Digital Projector and a Board & 27.4 & 16.9 & 33.0 & 22.7 & 2.59 \\
\hline Interactive Board & 69.3 & 12.2 & 13.7 & 4.8 & 1.45 \\
\hline TV & 71.6 & 13.5 & 12.4 & 2.5 & 1.40 \\
\hline Other & 0 & 0 & 2.3 & 0 & - \\
\hline
\end{tabular}

It was established that as many as $95.5 \%$ of teachers had a computer in their classroom, but almost a third of teachers used it only occasionally $(24.3 \%)$, or not at all (5.2\%). About half the respondents frequently $(33.0 \%)$ and daily $(22.7 \%)$ used a digital projector. During the education process, less than half of primary school teachers and students have taken advantage of the teaching/learning opportunities provided by mobile phones (often $14.8 \%$, daily $26.1 \%$ ), while almost as many teachers have never done so. There appeared a tendency that a lack of IT tools in primary schools limits opportunities for their use in the teaching/learning process. Since most teachers did not have interactive boards $(92.0 \%)$ or tablet computers $(94.3 \%)$ in their classrooms, more than half of teachers have never used these tools $(69.3 \%$ and $69.3 \%$ respectively), even though schools acquired the IT tools for shared use. Similar trends may be noticed in the use of televisions in the educational process: since $97.7 \%$ of respondents did not have a television in their classroom, $71.6 \%$ of respondents have never used one. There were no statistically significant differences in the answers to the question provided by teachers working in urban and non-urban schools.

The research revealed that IT tools are not always used effectively in the teaching/learning process. There is a lack of IT tools to be used by every primary grade, while IT tools acquired by the school for shared use are rarely used by primary school teachers.

Features in creating a health-promoting teaching/learning environment for children in terms of using information technologies. IT penetrates the everyday teaching/learning environment. The application of IT in the educational process undoubtedly has a positive effect on the cognition and development of a child. However, its improper use can have negative consequences for the health of the child. The natural need of children for new technologies, and the development of their use in the educational process, dictate the inevitable requirement to use IT tools in an effective and safe way. The research sought to find out teachers' attitudes towards the time per day spent by their students in front of a screen during educational activities (Table 2).

Table 2. Time spent per day by students in front of a screen during educational activities (\%)

\begin{tabular}{|l|l|l|l|l|l|l|l|}
\hline \multicolumn{1}{|c|}{ Statements } & $\begin{array}{c}\text { Do not } \\
\text { spend }\end{array}$ & $\begin{array}{c}\text { Up to 15 } \\
\text { minutes }\end{array}$ & $\begin{array}{c}\mathbf{1 5 - 3 0} \\
\text { minutes }\end{array}$ & $\begin{array}{c}\mathbf{3 0} \\
\text { minutes-1 } \\
\text { hour }\end{array}$ & $\begin{array}{c}\text { 1-2 } \\
\text { hours }\end{array}$ & $\begin{array}{c}\mathbf{2} \text { and } \\
\text { more } \\
\text { hours }\end{array}$ & \multicolumn{1}{|}{$\bar{X}$} \\
\hline Computer (personal and/or portable) & 20.8 & 52.3 & 14.9 & 5.4 & 5.5 & 1.1 & 2.20 \\
\hline Tablet Computer (Tablet) & 82.4 & 8.8 & 8.8 & 0 & 0 & 0 & 1.19 \\
\hline Mobile Phone (personal) & 63.8 & 20.5 & 10.2 & 5.5 & 0 & 0 & 1.57 \\
\hline Digital Projector and a Board & 29.1 & 20.5 & 30.7 & 17.5 & 1.1 & 1.1 & 2.37 \\
\hline Interactive Board & 70.8 & 13.5 & 12.3 & 3.4 & 0 & 0 & 1.38 \\
\hline TV & 85.5 & 7.7 & 0 & 0 & 5.7 & 1.1 & 1.37 \\
\hline Other & 0 & 1.1 & 0 & 0 & 0 & 0 & - \\
\hline
\end{tabular}


About half of teachers (52.3\%) claimed that their students spent up to 15 minutes a day on educational activities in front of a computer. Teachers working in non-urban schools were more receptive of the opinion $(U=496.500$, $\mathrm{p}=0.018$; average response rates of teachers working in urban schools $\bar{X}-34.03$, teachers working in non-urban schools $-\bar{X}-44.98$ ). A total of $30.7 \%$ of respondents claimed that children spent 15 to 30 minutes in front of a screen observing images produced by a digital projector, and the same number of respondents claimed that students used mobile phones for up to 15 minutes (20.5\%), and for 15 to 30 minutes (10.2\%).

The research revealed that, on average, primary school students spend about 30 minutes in front of a screen each day. Even though the time spent in front of a screen in a school corresponds to the recommended hygiene standards (the recommended time for junior school-age children to use IT should not be more than 45 minutes per day), it is necessary to determine the time spent in front of a screen at home after classes and at weekends. The educational process forms students' considerations that time spent in front of a screen can cause disabilities.

The use of IT is common for 21st-century students: they grow up with tools that enable the exchange of information and social communication, and digital language is familiar to them (Means, 2010). It should be noted that children give a lot of time to the use of IT, which results in the reduction of their physical activity (Adams, 2004), impaired vision, the occurrence of poor posture, and other disorders. Accordingly, the knowledge of the child, skills in using IT in a responsible and safe manner, and health-promoting behaviour, are essential today. The research aimed to find out teachers' opinions of their students' knowledge and skills in using IT (Table 3).

Table 3. Children's knowledge about health and skills in using IT (\%)

\begin{tabular}{|l|l|l|l|l|l|l|}
\hline \multicolumn{1}{|c|}{ Daily living skills } & $\begin{array}{l}\text { Strongly } \\
\text { disagree }\end{array}$ & Disagree & $\begin{array}{l}\text { Neither agree, } \\
\text { nor disagree }\end{array}$ & \multicolumn{1}{|c|}{ Agree } & $\begin{array}{c}\text { Strongly } \\
\text { agree }\end{array}$ & $\bar{X}$ \\
\hline Knows rules of safe behaviour & 0 & 2.3 & 28.4 & 5.7 & 13.6 & 3.83 \\
\hline $\begin{array}{l}\text { Knows consequences to health through } \\
\text { misuse of IT }\end{array}$ & 1.1 & 2.3 & 6.8 & 69.3 & 20.5 & 4.08 \\
\hline $\begin{array}{l}\text { Is able to play/work using IT in } \\
\text { accordance with duration determined by } \\
\text { the teacher }\end{array}$ & 0 & 14.8 & 22.7 & 47.7 & 14.8 & 3.68 \\
\hline Is able to take breaks & 0 & 19.3 & 29.6 & 42.0 & 9.1 & 3.42 \\
\hline Is able to sit properly at a desk & 1.1 & 31.8 & 44.4 & 21.6 & 1.1 & 2.90 \\
\hline Knows how to perform eye exercises & 1.1 & 43.2 & 39.6 & 16.1 & 0 & 2.69 \\
\hline $\begin{array}{l}\text { Knows how to protect vision (choosing } \\
\text { the proper distance, etc.) }\end{array}$ & 0 & 36.4 & 46.6 & 17.0 & 0 & 2.80 \\
\hline $\begin{array}{l}\text { Is able to combine eye and hand } \\
\text { movements }\end{array}$ & 0 & 34.1 & 53.4 & 11.4 & 1.1 & 2.79 \\
\hline $\begin{array}{l}\text { Performs movements with one hand } \\
\text { (right or left) while working/playing } \\
\text { using IT }\end{array}$ & 0 & 15.9 & 46.6 & 31.8 & 5.7 & 3.28 \\
\hline $\begin{array}{l}\text { Performs movements with both hands } \\
\text { (right and left) at the same time as } \\
\text { working/playing using IT }\end{array}$ & 4.5 & 11.4 & 54.5 & 22.8 & 6.8 & 3.16 \\
\hline $\begin{array}{l}\text { Performs movements with all fingers } \\
\text { (including the thumb) while working/ } \\
\text { playing with IT }\end{array}$ & 5.7 & 24.9 & 52.3 & 13.7 & 3.4 & 2.84 \\
\hline $\begin{array}{l}\text { Performs movements with one or two } \\
\text { fingers while working/playing with IT }\end{array}$ & 6.8 & 19.5 & 53.4 & 16.9 & 3.4 & 2.91 \\
\hline $\begin{array}{l}\text { Is able to control fingers and a computer } \\
\text { mouse in a coordinated way while using } \\
\text { the computer }\end{array}$ & 0 & 4.5 & 45.5 & 38.6 & 11.4 & 3.59 \\
\hline $\begin{array}{l}\text { Willingly develops skills needed for a } \\
\text { healthy daily life }\end{array}$ & 0 & 15.9 & 49.9 & 29.8 & 4.4 & 3.24 \\
\hline
\end{tabular}




\begin{tabular}{|l|l|l|l|l|l|l|l|}
\hline \multicolumn{2}{|c|}{ Daily living skills } & \multicolumn{1}{|c|}{$\begin{array}{c}\text { Strongly } \\
\text { disagree }\end{array}$} & Disagree & $\begin{array}{c}\text { Neither agree, } \\
\text { nor disagree }\end{array}$ & Agree & $\begin{array}{c}\text { Strongly } \\
\text { agree }\end{array}$ & \multicolumn{1}{|c|}{$\bar{X}$} \\
\hline Physical activity & 0 & 1.1 & 1.1 & 54.9 & 42.9 & 4.39 \\
\hline $\begin{array}{l}\text { Knows the importance of active } \\
\text { movements }\end{array}$ & 0 & 1.1 & 5.1 & 34.7 & 59.1 & 4.55 \\
\hline $\begin{array}{l}\text { Willingly and joyfully moves, likes } \\
\text { lively activities and games }\end{array}$ & 3.4 & 5.7 & 30.7 & 50.0 & 10.2 & 3.59 \\
\hline $\begin{array}{l}\text { Performs spontaneous and targeted } \\
\text { activities that require eye-hand } \\
\text { coordination and advanced fine motor } \\
\text { skills }\end{array}$ & & & & & \\
\hline
\end{tabular}

More than half of teachers believe that primary school students know:

- the rules of safe behaviour while using IT (agree 55.7\%, strongly agree 13.6\%);

- the consequences to health of the misuse of IT (agree $69.3 \%$, strongly agree $20.5 \%$ ).

About half of respondents believe that children are able to:

- play/work using IT in accordance with the duration determined by the teacher (agree $47.7 \%$, strongly agree $14.8 \%$ );

- perform movements with one hand (right or left) while working/playing using IT (agree $31.8 \%$, strongly agree $5.7 \%$ );

- control fingers and a computer mouse in a coordinated way while using the computer (agree $38.6 \%$, strongly agree $11.4 \%$.); take a break while using IT (agree $42.0 \%$, strongly agree $9.1 \%$ ). Teachers working in urban schools were more receptive of the opinion about taking breaks while using IT ( $\mathrm{U}=$ $552.000, \mathrm{p}=0.015$; average response rates of teachers working in urban schools $\bar{X}-46.00$, teachers

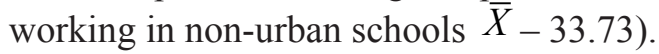

About half of respondents did not express a clear opinion on the following aspects: children perform movements with both hands (right and left) at the same time as working/playing with IT (54.5\%), perform movements with all fingers (including the thumb) while working/playing with IT (52.3\%), perform movements with one or two fingers while working/playing with IT (53.4\%).

About a third of primary school teachers did not agree that primary school students are able to (in other words, primary school students are not able to):

- sit properly at a desk (disagree $31.8 \%$, strongly disagree $1.1 \%$ );

- perform eye exercises (disagree $43.2 \%$, strongly disagree $1.1 \%$ ), look after their vision (choose the proper distance, etc) while using IT (disagree $36.4 \%$ );

- combine eye and hand movements (disagree $34.1 \%$ ).

Despite the fact that primary school teachers claim that their students have a basic knowledge about health care (safe behaviour, knowledge of the consequences of the misuse of IT, etc), they lack ability in health preservation (children are not able to take breaks, sit properly, protect their vision, etc). Thus, it can be stated that primary school students particularly lack practical abilities and their application in life situations, and health promoting behaviour.

The skill and competence of teachers determine students' preparation for a health-promoting life in rapidly changing social and cultural conditions. Teachers have an important role: they help a person mature to play an active part in the age of technology, and for the holistic development of a personality, by applying modern and effective ways of ensuring health (Sandercock, Ogunleye, Voss, 2013). The research sought to identify how primary school teachers strengthen children's health while using IT (Table 4). 
Table 4. Methods used by teachers to preserve and strengthen children's health when using IT, in educational reality (\%)

\begin{tabular}{|c|c|c|c|c|c|c|}
\hline Statements & $\begin{array}{l}\text { Strongly } \\
\text { disagree }\end{array}$ & Disagree & \begin{tabular}{|c|} 
Neither \\
agree, nor \\
disagree
\end{tabular} & Agree & $\begin{array}{l}\text { Strongly } \\
\text { agree }\end{array}$ & $\bar{X}$ \\
\hline $\begin{array}{l}\text { Inform and determine duration of time for using } \\
\text { IT for children (up to } 30 \text { minutes per day) }\end{array}$ & 0 & 1.1 & 28.5 & 51.1 & 19.3 & 3.89 \\
\hline Talk to children about the safe use of IT & 0 & 0 & 7.9 & 55.7 & 36.4 & 4.28 \\
\hline $\begin{array}{l}\text { Individually encourage to take breaks while using } \\
\text { IT (10-15 minutes) }\end{array}$ & 0 & 0 & 17.0 & 58.0 & 25.0 & 4.09 \\
\hline $\begin{array}{l}\text { Encourage active movements during breaks } \\
\text { (organise games, exercises, etc) }\end{array}$ & 2.3 & 2.3 & 34.0 & 40.9 & 20.5 & 3.75 \\
\hline $\begin{array}{l}\text { Encourage and teach children to perform eye } \\
\text { exercises during breaks }\end{array}$ & 1.1 & 21.6 & 22.8 & 37.5 & 17.0 & 3.48 \\
\hline $\begin{array}{l}\text { Control the proper posture of children when sitting } \\
\text { at the desk }\end{array}$ & 1.1 & 1.1 & 13.7 & 46.6 & 37.5 & 4.21 \\
\hline $\begin{array}{l}\text { Adjust the size of characters on the screen, so that } \\
\text { they are not too small or illegible }\end{array}$ & 3.4 & 3.4 & 18.2 & 39.8 & 35.2 & 4.00 \\
\hline Encourage to move after using IT & 1.1 & 3.4 & 29.6 & 42.0 & 23.9 & 3.84 \\
\hline $\begin{array}{l}\text { Clean/make others clean dust from the monitor } \\
\text { screen or do it together with children }\end{array}$ & 6.4 & 11.4 & 27.7 & 37.5 & 17.0 & 3.47 \\
\hline $\begin{array}{l}\text { Provide knowledge about the consequences to } \\
\text { health of the misuse of IT }\end{array}$ & 0 & 0 & 4.6 & 44.3 & 51.1 & 4.47 \\
\hline Other & 0 & 0 & 0 & 2,3 & 0 & - \\
\hline
\end{tabular}

The results of the research show that more than half of respondents:

- provide knowledge: talk to children about the safe use of IT (agree $55.7 \%$, strongly agree $36.4 \%$ ), provide knowledge about the consequences to health of the misuse of IT (agree $44.3 \%$, strongly agree $51.1 \%$ ), inform and determine the duration of time using IT for children (up to 30 minutes per day) (agree $51.1 \%$, strongly agree $19.3 \%$ );

- encourage active movement: take breaks (10 to 15 minutes) (agree $58.0 \%$, strongly agree $25.0 \%$ ), actively move during breaks (agree $40.9 \%$, strongly agree $20.5 \%$ ), move after using IT (agree $42.0 \%$, strongly agree $23.9 \%$ );

- control posture and help to protect vision: promote proper posture while sitting in front of a computer (agree $46.6 \%$, strongly agree $37.5 \%$ ), adjust the size of the characters on the screen so that they are not too small or illegible (agree $39.8 \%$, strongly agree $35.2 \%$ ).

About half or less than half of respondents encourage and teach children to perform eye exercises during breaks (agree 37.5\%, strongly agree 17.0\%), clean/make others clean dust from the monitor screen or do it together with the children (agree 37.5\%, strongly agree 17.0\%). There were no statistically significant differences in answers to the question provided between teachers working in urban and those working in non-urban schools, $\mathrm{p}>0.05$.

Despite the fact that primary school teachers apply various methods for protecting and strengthening children's health while using IT, the means of promoting activity (active breaks, organisation of active movements, performance of exercises, etc) and the rules for using and maintaining IT tools (adjustment of the size of characters, lighting, cleaning of dust from the screen, etc) are still underdeveloped. Basic health-care skills, formed and embedded by modelling various life situations, and solving child-relevant problems, establish the preconditions for children to easily transfer existing skills by learning and individually using IT tools at home. 


\section{Conclusions and discussion}

IT is an important criterion in modern schools for improving the quality of the education process that affects the school culture and changes the traditional learning style. The research revealed that teachers do not yet have enough opportunities to use various IT tools in the educational process. The computer is the dominant IT tool in the primary school environment.

Teachers who do not teach computer science but wish to have access to computers and apply them in the teaching/learning process, face barriers (Merkys et al., 2007). Even though it is claimed that computers have become an integral part of the educational process and school management, almost half of all the available computers are located in computer science classrooms. It is believed that, at best, primary school students are allocated $6 \%$ of computers in other premises, as computer science classrooms are used by senior students, while junior primary school students are admitted to subject classrooms only on a case-by-case basis, after the prior agreement of the teacher (Paulionyte et al., 2010). Research carried out by J. Uginčienė and E. Dargyte (2008) revealed that most teachers underestimate their preparation to apply IT in education. The main reasons why participants in the research do not apply IT in their activities are the lack of technology or its inaccessibility, and features of the organisation of the education process. The results of our research correspond with the results of the above-mentioned authors. Despite the fact that primary schools have acquired various IT tools for shared use, primary school teachers lack them in their classrooms. The research revealed that a lack of IT tools in primary school classrooms limits the opportunities for their use. Since most teachers did not have an interactive board $(92.0 \%)$ or tablet computers $(94.3 \%)$ in their classrooms, more than half of teachers have never used them $(69.3 \%$ and $69.3 \%$ respectively), even though the school has acquired the IT tools for shared use. According to T. Kriliuvienè (2008), a very small percentage (2.3\%) of usage of an interactive board gives cause for consideration. The results of our research confirm the results of the abovementioned study: $69.3 \%$ of primary school teachers have never used an interactive board, while $12.2 \%$ of teachers have used one only occasionally.

Research carried out by G. Merkis et al. (2007) revealed that teachers working in urban schools have more favourable opportunities for applying IT compared to those working in non-urban schools. According to data from the research, only a third of teachers working in non-urban schools assessed the opportunities for applying IT in the educational process as being great, while a quarter of teachers working in non-urban schools noted that they do not have opportunities to apply IT in their work. According to the data from our research, there were no significant differences in the application of IT tools in the educational process between teachers working in urban and non-urban schools.

The research showed that, on average, primary school students spend about 30 minutes every day in front of a screen in school. Even though the time spent in front of a screen in school corresponds to the recommended norms, it is not known how much additional time is spent in front of a screen at home.

Scientific literature highlights the importance of the IT competency of a teacher as an integral part of all pedagogical competence. It has been emphasised that the IT competencies of a teacher (knowledge, skills, attitudes, values, and other personal qualities) determine the successful use of IT in pedagogical activities. Pedagogical knowledge is related to IT tools, the ability to apply them, and the purposeful use of IT, by focusing on computer networks and the constructivist paradigm of learning (integrative, project-based learning, collaborative learning, etc) (Paulionyte et al., 2010). It should be noted, however, that the IT competencies of a teacher should be related to knowledge, skills and attitude towards the protection and enhancement of children's health. After all, a teacher is a student's assistant in the educational process, who enables the young person to perceive health as the greatest value, understand how to learn, and be able to preserve and strengthen their health in the modern educational environment. Our research has revealed that primary school students' knowledge about the safe use of IT tools and the preservation of health while using IT are not related to ability. Children lack the acquisition of practical activities, the ability to apply them in life situations, and health-promoting behaviour. Even though most teachers believe that primary school students know the rules for the safe use of IT and the consequences to health of their misuse, only a third or even a 
smaller number of primary school teachers agreed that primary school students of such an age are able to sit properly at a desk while using IT, know how to perform eye exercises, protect their vision, and coordinate eye and hand movements, etc. It is obvious that the goal of modern primary education is to create a healthpromoting educational environment for the child within the context of IT development.

\section{References}

Adams, J. M., White, M. (2004). Biological ageing. A fundamental, biological link between socio-economic status and health? European Journal of Public Health, Vol. 14 (3), p. 331-334.

Adaškevičienè, E., Strazdienè, N. (2017). Mokiniu fizinio aktyvumo edukacija. Klaipėda: KU leidykla.

Are the New Millennium Learners Making the Grade? (2010). Technology Use and Educational Performance in PISA 2006. Internet access: http://www.oecd.org/education/ceri/45053490.pdf [accessed: 2018-05-25].

Bacys, T. (2012). Paaugliu priklausomybė nuo socialinių tinklų internetinèje erdvėje. Jaunimo problemos ir ju ìveika. Internet access: http://www.zurnalai.vu.lt/socialine-teorija-empirija-politika-ir praktika/article/viewFile/1390/779 [accessed: 2018-09-02].

Bassiouni, D. H., Hackley, C. (2014). Generation Z children's adaptation to digital consumer culture. A critical literature review. Journal of Customer Behaviour, Vol. 13 (2), p. 113-133.

Bitinas, B., Rupšienė, L., Žydžiūnaitè, V. (2008). Kokybiniu tyrimu metodologija. Klaipèda: S. Jokužio leidykla.

Brazdeikis, V. (2009). Informacinėmis ir komunikacinėmis technologijomis papildytų edukacinių aplinkų kaita. Informacijos mokslai, Nr. 50, p. 57-63.

Brunes, A., Augestad, L. B., Gudmundsdottir, S. L. (2013). Personality, physical activity, and symptoms of anxiety and depression: the HUNT study. Social psychiatry and psychiatric epidemiology, Vol. 48 (5), p. 745-756.

Burianova, M., Turčáni, M. (2016). Non-traditional Education Using Smart Devices. DIVAI-2016 The $11^{\text {th }}$ international scientific conference on Distance Learning in Applied Informatics. Wolters Kluwer, p. 77-86.

Chan, M., Lake, A., Hansen, K. (2017). The early years: silent emergency or unique opportunity? The Lancet, Vol. 389 (10064), p. 11-13.

Dugdill, L., Crone, D., Murphy, R. (2009). Physical Activity and Health Promotion: Evidence-based Approaches to Practice. Wiley-Blackwell Publishing.

Glahn, C., Specht, M., Mwishart, J. (2011). Towards Mobile Learning Support for the Transition from School to the Workplace. Internet access: http://dspace.eu.nl/handle/1820/1381v [accessed: 2018-09-05].

Girdzijauskienė, R., Gudynas, P., Jakavonytė, D., Jevsikova, T. (2010). Inovatyviu mokymo(si) metodu ir IKT taikymas. Metodinè priemonè pradinių klasių mokytojams ir specialiesiems pedagogams. 1 knyga. Vilnius: Ugdymo plètotès centras.

Gudonienė, D., Rutkauskienė, D., Lauraitis, A. (2013). Pažangių mokymosi technologijų naudojimas ugdymo procese. Informacijos mokslai, Nr. 66, p. 96-107.

Hastings, E. C., Karas, T. L., Winsler, A., Way, E., Wadigan, A., Tyler S. (2009). Young Children's Video / Computer Game Use: Relations with School Performance and Behavior. Issues in Mental Health Nursing, Vol. 30(10), p. 638-649.

Holt, K. (2015). The Impact of Technology on Primary Education. Internet access: https://digitalcommons.csumb.edu/ cgi/viewcontent.cgi? article $=1482 \&$ context $=$ caps thes [accessed: $2018-05-25]$.

Kriliuvienè, T. (2008). Tyrimo „Sukauptos metodinès patirties, naudojant IKT ịvairiuose dalykuose“ analizè. Ataskaita. Internet access: https://www.itc.smm.lt/wp-content/uploads/2009/11/tyrimas_metodika.pdf [accessed: 2018-02-25].

Lafuente, M. (2017). Getting looped in to the web: Characterizing learning processes and educational responses. Interactive Learning Environments, Vol. 25 (1), p. 72-84.

Lawrence, J. E., Tar, U. A. (2018) Factors that influence teachers' adoption and integration of ICT in teaching/learning process. Educational Media International, Vol. 55(1), p. 79-105. Internet access: https://doi.org/10.1080/0952398 7.2018.1439712

Martišienè, D., Muleravičienė, R. (2010). E-mokymo/si aplinkas formuojantys elementai. Informaciniu technologiju taikymas švietimo sistemoje. Kaunas: Kauno technikos kolegija.

Means, B. (2010). Technology and Education Change: Focus on Student Learning. Journal of Research on Technology in Education, Vol. 42 (3), p. 285-307.

Merkys, G., Urbonaitė-Šlyžiuvienė, D., Balčiūnas, S., Mikutavičienė, I. (2007). IKT taikymas ugdyme. Sites 2006 Lietuva. Statistinio tyrimo ataskaita. Internet access: http://www.ipc.lt/?page id=1805 [accessed: 2018-09-20].

Pekka Mertala. (2019). Digital technologies in early childhood education - a frame analysis of preservice teachers' perceptions. Early Child Development and Care, Vol. 189(8), p. 1228-1241. Internet access: https://doi.org/10.108 0/03004430.2017.1372756 
McCrindle, M. (2014). The ABC of XYZ: Understanding the Global Generations. University of New South Wales Press.

Mirascieva, S., Petrova, G. E., Stavreva, V. S. (2017). Application of new techniques and technologies in kindergartens from the perspective of preschool teachers. Competences of preschool teachers for the knowledge society, Vol. 1 (1), p. $92-104$.

Parigi, L. (2016). Balancing between ICT training and reflective practice in teachers professional development. $T D$ Technologie Didattiche, Vol. 24 (2), p. 111-121.

Patel, A. V., Bernstein, L., Deka, A., Feigelson, H. S., Campbell, P. T., Gapstur, S. M., Colditz, G. A., Thun, M. J. (2010). Leisure Time Spent Sitting in Relation to Total Mortality in a Prospective Cohort of US Adults. American Journal of Epidemiology, Vol. 183 (10), p. 1-10.

Paulionyte, J., Grabauskienė, V., Țemgulienè, A., Schoroškienė, V., Makarskaitè-Petkevičienè, R. (2010). IKT ir inovatyviu mokymo(si) metodu taikymo pradiniame ir specialiajame ugdyme pasiūla, taikymo praktika ir perspektyvos Lietuvoje ir užsienyje. Internet access: http://www.inovacijos.upc.smm.lt/uploads/ATASKAITA_TEORINE_ STUDIJA.pdf [accessed: 2018-09-20].

Rupšienè, L. (2007). Kokybinio tyrimo duomenu rinkimo metodologija. Klaipėda: KU Publishing House.

Sandercock, G. R. H., Ogunleye, A., Voss, C. (2013). Screen Time and Physical Activity in Youth: Thief of Time or Lifestyle Choice. Journal of Physical Activity and Health, Vol. 9(7), p. 977-984.

Sangra, A., González-Sanmamed, M. (2010). The role of information and communication technologies in improving teaching and learning processes in primary and secondary schools. Research in Learning Technology, Vol. 18 (3), p. $207-220$.

Tidikis, R. (2003). Socialiniu mokslu tyrimu metodologija. Vilnius: Lietuvos teisès universitetas

Uginčienė, E., Dargienė, J. (2008). Projekto „Pradiniu klasių ir specialiojo ugdymo pedagogu kompetenciju taikyti IKT ir inovatyvius mokymo(si) metodus tobulinimas "veiksmingumo tyrimas. Tyrimo trečiojo etapo ataskaita. Internet access: http://inovacijos.pedagogika.lt/lt/ [accessed: 2018-05-25].

Žydžiūnaite, V. (2006). Taikomuju tyrimu metodologijos charakteristikos. LR Švietimo ir mokslo ministerija.

Wajszczyk, R. (2014). A study of the impact of technology in early education. Internet access: http://www.diva-portal. org/smash/get/diva2:737018/FULLTEXT01.pdf [accessed: 2018-09-05].

Vartiainen H., Leinonen T., Nissinen S. (2019). Connected learning with media tools in kindergarten: an illustrative case. Educational Media International. Internet access: https://doi.org/10.1080/09523987.2019.1669877.

Vilkonienė, M. (2009). Informacinių komunikacinių technologijų diegimo ir taikymo švietime įtaka pedagoginės sistemos kaitai: diskurso analizè. Pedagogika, Nr. 95, p. 126-133.

\title{
VAIKU SVEIKATAI PALANKIOS MOKYMO(SI) APLINKOS KÜRIMO YPATUMAI: INFORMACINIUCTECHNOLOGIJU PLÉTROS PRADINIO UGDYMO PROCESE KONTEKSTAS
}

\author{
Neringa StrazdienE, Aida Norviliené, Lauryna EirošĖ \\ Klaipėdos universitetas (Lietuva)
}

\section{Santrauka}

Informacinių technologijų (toliau - IT) plètra šiuolaikinio pradinio ugdymo(si) procese šio proceso dalyviams kelia naujus iššūkius. Viena vertus, modernizuojant ugdymo turinį ir mokymo(si) metodus, keičiant ugdymo(si) aplinką, taikant IT, mokymo(si) procesas tampa šiuolaikiškas, patrauklus. Kita vertus, neribotai ir neatsakingai naudojamos IT gali turèti neigiamų pasekmių tiek fizinei, tiek ir psichinei jaunesniojo mokyklinio amžiaus vaikų sveikatai. Straipsnyje analizuojami vaikų sveikatai palankios mokymo(si) aplinkos kūrimo ypatumai IT plètros pradinio ugdymo procese kontekste. Keliamas tikslas - atskleisti pedagogų nuomones apie jaunesniojo mokyklinio amžiaus vaikų sveikatai palankios mokymo(si) aplinkos kūrimo galimybes IT naudojimo aspektu. Taikant apklausos raštu (anketavimo) tyrimo metodą apklausti 237 Vakarų Lietuvos regiono pradiniu klasių mokytojai. Taikyta: matematinès ir aprašomosios statistikos metodai, SPSS programa (23.0 versija), Stjudento $t$ kriterijus, chi kvadrato $\left(\chi^{2}\right)$ testas, Spirmeno koreliacijos koeficientas $\left(r_{s}\right)$. 
Tyrimo rezultatai atskleide, kad pagrindinè IT priemonė pradinio ugdymo aplinkoje - kompiuteris. Savo klasėse jị turejo beveik visi apklausti mokytojai. Tačiau kompiuterị mokytojai dažniausia naudojo rengdamiesi pamokoms arba darbui su skaitmeniniu projektoriumi, kurị savo klasėse turèjo beveik pusė apklaustụjų. Tyrimas atskleidè, kad pedagogams, ypač pradinio ugdymo, trūksta interaktyviųjų lentų ir planšetinių kompiuterių. Juos savo klasėje turejjo tik labai nedaug mokytojų. Nors mokyklose yra įvairių IT priemonių, jos naudojamos bendrai, o tai kelia problemų: ne visi mokytojai gali tuo pačiu metu naudotis IT priemonèmis, nèra galimybės kiekvieną pamoką nusivesti mokinius ị klases, kuriose IT priemonės įrengtos stacionariai, jos dažniau genda ir kt. Todèl pradinių klasių mokytojai pasigenda ịvairesnių IT priemonių savo klasėse. Bendrai mokykloje naudojamos IT priemonès yra mažai veiksmingos, o jų trūkumas pradinio ugdymo klasėse riboja IT priemonių taikymo ugdymo procese galimybes.

Tyrimo rezultatai atskleide, nors pradinių klasių mokiniai informuoti apie saugų IT priemonių naudojimą ir būtinybę saugoti sveikatą dirbant su IT, turimų žinių taikyti praktiškai nesugeba. Vaikams reikia išmokti atlikti veiksmus praktiškai, juos gebėti taikyti gyvenimiškose situacijose.

Daugelis apklaustų pedagogų mano, kad jaunesniojo mokyklinio amžiaus vaikai yra susipažinę su saugaus naudojimosi IT taisyklèmis ir netinkamo naudojimosi IT pasekmėmis sveikatai. Tačiau tik trečdalis ir dar mažiau pedagogų sutiko, kad pradinių klasių mokiniai naudodamiesi IT geba taisyklingai sèdèti prie rašomojo stalo, saugoti savo regejjimą, daryti akių pratimus, derinti atliekamus akių ir rankų judesius ir kt. Todèl kuriant jaunesniojo mokyklinio amžiaus vaikų sveikatai palankią ugdymo(si) aplinką IT kontekste svarbios ne tik šiuolaikiškos IT priemonès, jų saugus įrengimas, bet ir saugios bei vaikų sveikatai palankios elgsenos su IT priemonėmis ugdymas: darbo su IT priemonėmis reglamentavimas ir paskirstymas mokykloje bei namuose, atsakingas IT naudojimas; ne tik žinių, kaip naudoti IT, mokinimas perteikimas, bet ir praktinių igūdžių ugdymas, jų taikymas gyvenimiškose situacijose.

PAGRINDINIAI ŽODŽIAI: sveikatai palanki mokymo(si) aplinka, mokytojai, pradiniu klasiu mokiniai, informacinès technologijos.

JEL KLASIFIKACIJA: I12, I21; I31.

Received: 2020-09-02

Revised: 2020-09-17

Accepted: 2020-10-10 